\title{
Pengaruh Penggunaan Aplikasi TikTok Terhadap Kepercayaan Diri Remaja di Kabupaten Sampang
}

\author{
Dwi Putri Robiatul Adawiyah \\ Pascasarjana Komunikasi Penyiaran Islam Universitas Islam Negeri Sunan Ampel Surabaya \\ Email : putrirad@gmail.com
}

DOI: https://doi.org/10.21107/ilkom.v14i2.7504

\begin{abstract}
ABSTRAK
Semakin banyaknya pengguna media sosial TikTok pada remaja di Indonesia tentu akan berpengaruh terhadap salah satu tahap perkembangan remaja yakni mengenai kepercayaan diri. Memiliki kepercayaan diri sangat penting hal ini dikarenakan seorang remaja akan mampu untuk menilai diri sendiri dan melakukan suatu pekerjaan secara efektif di dalam kehidupannya. Penelitian ini menggunakan metode penelitian kuantitatif dengan paradigma positivistik. Pengumpulan data dilakukan dengan cara penyebaran kuesioner sesuai dengan kriteria sampel yang telah ditentukan. Sampel pada penelitian kali ini yakni remaja dengan usia 15-19 tahun di Kabupaten Sampang. Tinjauan pustaka ini dimulai mengenai penggunaan media sosial TikTok sampai pengaruhnya terhadap kepercayaan diri remaja yang kemudian berhubungan dengan teori uses and gratification. Teori ini menjelaskan mengenai konsekuensi keterlibatan individu secara aktif maupun kurang aktif dalam media. Setiap individu memiliki tingkat kebutuhan yang berbeda dalam menggunakan media. Salah satu kebutuhan yang ingin dipenuhi seseorang yakni mengenai peningkatan kepercayaan diri. Penelitian ini menggunakan analisis regresi linier sederhana. Hasil penelitian mengungkapkan bahwa terdapat pengaruh yang signifikan dari penggunaan media sosial TikTok terhadap kepercayaan diri remaja sebesar $54,5 \%$.
\end{abstract}

Kata kunci : Media Sosial TikTok, Kepercayaan Diri, dan Teori Uses and Gratification.

\begin{abstract}
The growing number of TikTok social media users in mid teens in Indonesia will certainly affect the task of adolescent development regarding self-confidence. Having self-confidence is very important because a teenager will be able to judge himself and do a job effectively. This study uses quantitative research methods with a positivistic paradigm. Data collection was carried out by distributing questionnaires according to the sample criteria that had been done. The sample in this study is adolescents aged 15-19 years in Sampang Regency. This literature review starts with the use of TikTok social media to its influence on adolescent selfconfidence to the uses and gratification theory that provides an understanding of the consequences of active and less active involvement of individuals in consuming media to the explanation of the need for increased self-confidence. This research uses simple linear regression analysis. The results revealed that there was a significant effect of the use of TikTok social media on adolescent self confidence of $54.5 \%$.
\end{abstract}

Keywords: TikTok Social Media, Self Confidence, and Theory of Uses and Gratification.

\section{Cite this as :}

Adawiyah, Dwi Putri Robiatul (2020). Pengaruh Penggunaan Aplikasi TikTok terhadap Kepercayaan Diri Remaja di Kabupaten Sampang. Jurnal Komunikasi, 14(2), 135-148. Doi : https://doi.org/10.21107/ilkom.v14i2.7504

Article History :

Received Juni, $11^{\text {th }} 2020$, Acepted August, 03 ${ }^{\text {th }} 2020$ 


\section{PENDAHULUAN}

Tik Tok merupakan salah satu aplikasi yang paling terpopuler dan diminati di dunia. Tik Tok memungkinkan penggunanya membuat video berdurasi 15 detik disertai musik, filter, dan beberapa fitur kreatif lainnya. Aplikasi ini diluncurkan oleh perusahaan asal Tiongkok, China, ByteDance pertama kali meluncurkan aplikasi yang memiliki durasi pendek yang bernama Douyin. Hanya dalam waktu 1 tahun, Douyin memiliki 100 juta pengguna dan 1 miliar tayangan video setiap hari. Popularitas Douyin yang tinggi membuatnya melakukan perluasan ke luar China dengan nama Tik Tok. Menurut laporan dari Sensor Tower, aplikasi ini diunduh 700 juta kali sepanjang tahun 2019. Hal ini membuat Tik Tok dapat mengungguli sebagian aplikasi yang berada dibawah naungan Facebook Inc. aplikasi ini menempati peringkat ke dua setelah Whatsapp yang memiliki 1,5 miliar pengunduh (Kusuma, 2020).

Di Indonesia Pada tahun 2018 aplikasi ini dinobatkan sebagai aplikasi terbaik di Play store yang dimiliki oleh Google. Tidak hanya itu, Tik Tok juga menjadi kategori aplikasi paling menghibur (Imron, 2018). Pada Juli lalu Aplikasi buatan China itu sempat diblokir oleh Kementrian Komunikasi dan Informatika (Kominfo) di pertengahan 2018, alasannya karena adanya konten-konten yang negatif, terutama bagi anak-anak. Pemblokiran pada aplikasi ini hanya berlangung seminggu, mulai 3-10 Juli 2018. (Kusuma, 2020).

Aplikasi ini banyak digemari oleh para remaja, anak kecil, bahkan sampai pada orang dewasa yang merasa mmbutuhkan hiburan. Konon aplikasi ini memiliki nama lain aplikasi "goblok". Banyaknya anak muda maupun dewasa yang membuat dan memposting video diberbagai platform media sosialnya membuat tidak hanya aplikasi ini semakin popular namun orang yang menggunakan aplikasi "goblok" ini ikut popular (Hariansyah, 2018). Tik Tok memiliki ciri khas sendiri. Video yang diunggah oleh Tik Tok memiliki "watermark" berupa username yang membedakannya dengan aplikasi lainnya.

Aplikasi ini banyak digunakan oleh berbagai macam orang dari segala umur tidak menutup kemungkinan terdapat kontenkonten yang mengandung unsur negatif di dalamnya. Adanya konten-konten negatif tersebut tentunya dapat membahayakan untuk perkembangan mental penggunanya yang rata-rata remaja yang berusia di bawah 18 tahun karena belum stabilnya dari segi pendirian maupun pemikiran. Masa remaja merupakan masa peralihan dari anak-anak menuju dewasa dalam hal ini terdapat perkembangan baik itu secara fisik maupun mental. Terdapat batasan usia yang umunya digunakan oleh ahli antara 12 sampai 21 tahun, dapat dikelompokkan antara lain, remaja awal memiliki rentang usia 12-15 tahun, remaja pertengahan 15-18 tahun dan remaja akhir yang memiliki rentang usia 1821 tahun (Desmita, 2010).

Masa remaja merupakan masa perkembangan yang akan dilewati oleh individu. Sedangkan masa perkembangan remaja adalah masa ketika mencapai kematangan mental, emosional, sosial, fisik, yang merupakan periode perkembangan individu pada masa peralihan dari masa anakanak menuju dewasa. Hal ini mengakibatkan perbedaan karakteristik antara satu dengan yang lain. Perubahan baik secara fisik maupun psikis serta kehidupan sosial yang mendatangkan berbagai persoalan dan tantangan. (Fitri dkk, 2018).

Dalam hal ini terdapat beberapa hal tugas perkembangan remaja, yang salah satunya mengenai Kepercayaan Diri (Singgih, 2008). Kepercayaan diri (self confidence) merupakan percaya pada kemampuan dan penilaian diri sendiri untuk dapat melakukan suatu pekerjaan serta mencari keefektifan pendekatan yang diperlukan. Kepercayaan diri yang mengarah pada hal-hal positif, ketika seorang individu memiliki sifa optimisme dan menerima kemampuan diri sendiri dalam menghadapi segala hal baik oleh dirinya maupun lingkungannya secara bebas dan yakin. 
Terdapat empat ahli (dalam Kartini, 2019) memberikan penjabaran mengenai pengertian dari Kepercayaan Diri antara lain, yang pertama Menururt Hakim dalam Kartini, 2019) berpendapat Kepercayaan Diri merupakan segala sesuatu dimana dapat mencapai tujuan dalam hidupnya disertai dengan keyakinan positif tentang kelebihan yang dimilikinya. Kedua Menururt Hambly (dalam Kartini, 2019) menyatakan percaya diri adalah ketika seseorang dapat melakukan sesuatu dengan tenang yang dipenuhi keyakinan dirinya. Ketiga Menurut Fereira (dalam Kartini, 2019) berpendapat percaya diri ialah ketika seseorang dapat menjaga dan mengendalikan keyakinan dirinya. Dapat mengubah sesuatu yang ada dalam lingkungannya yang berarti bahwa seseorang tersebut memiliki Kepercayaan diri untuk dapat mempengaruhi, mengendalikan, motivasi, empati dan keterampilan sosial.

Terakhir Coleman (dalam Kartini, 2019) berpendapat bahwa percaya diri merupakan kemampuan dan harga diri disertai dengan kesadaran diri yang kuat. Ketika seseorang percaya diri, ia berani menunjukkan diri dengan penuh keyakinan, berani menunjukkan keberadaannya, berani untuk menyatakan perbedaan pendapatnya dengan yang lainnya, serta dapat secara mandiri membuat keputusan meskipun dalam kondisi yang sulit. Serta dengan berani melakukan pengorbanan demi kebenaran.

Terlepas dari pengertian mengenai Kepercayaan Diri. Terdapat beberapa faktorfaktor yang mempengaruhi Kepercayaan Diri seseorang (Kartini, 2019) yakni:

\section{Keadaan Fisik}

Suryabrata mengemukakan ketika seseorang memiliki keadaan fisik yang berbeda dengan keadaan orang pada umumnya maka muncullah perasaan tidak berharga dan perasaan kurang nyaman akan dirinya sendri dibandingkan dengan sesamanya yang memiliki fisik sempurna. Perasaan ini menyebabkan seseorang kurang percaya diri karena perasaan rendah diri akan kondisi fisiknya.

\section{Konsep Diri (Self Concept)}

Konsep diri merupakan keyakinan, perasaan, cara pandang, dan pemikiran tentang segala sesuatu yang dimiliki oleh dirinya. Terdapat sikap, perasaan, karakter diri, kemampuan, tujuan hidup, kebutuhan dan penampilan diri. Menurut Coleman Kepercayaan Diri seseorang didapatkan dari mengetahui dan memahami diri sendiri secara penuh. Psikologis, aspirasi, prestasi, karakteristik fisik, dan tingkat emosional dapat mempengaruhi konsep diri. Maslow (dalam Kartini, 2019) mengungkapkan Kepercayaan Diri berawal dari konsep diri.

Sullivan berpendapat, konsep diri memiliki makna menerima akan identitas diri yang merupakan salah satu bentuk kestabilan konsep inti. Lingkungan dan individu dapat dipengaruhi oleh konsep dirinya, seperti halnya yang diungkapkan oleh Jiang (2000) perkembangan sosial yang positif berasal dari konsep diri dan Kepercayaan Diri yang baik. Ketika seseorang memiliki konsep diri yang positif, dalam kehidupan pergaulan seharihari maupun ketika menghadapi teman sebayanya tidak akan memiliki rasa cemas, takut, kesepian serta rasa gelisah yang berlebihan, melainkan sebaliknya rasa bebas dan optimis yang ada dalam dirinya.

\section{Harga Diri}

Robbinsun dan Shater (dalam Ramdhani, 1991) mengungkapkan harga diri sebagai bentuk rasa menghargai dan menguasai diri sendiri sesuai dengan hal-hal yang realistis. Perasaan seperti ini berpengaruh terhadap keinginan, perasaan, nilai, tujuan, proses berpikir mengenai hidup seseorang. Kepercayaan Diri seseorang dipengaruhi oleh harga dirinya. Hal senada diungkapkan oleh Cohen (dalam Azwar, 2000) harga diri yang tinggi mempengaruhi Kepercayaan Diri seseorang. Semakin seseorang memiliki harga diri yang tinggi semakin tinggi pula Kepercayaan Diri nya dibandingkan dengan seseorang yang mempunyai harga diri rendah.

Sedangkan Maslow (dalam Azwar, 2000) mengungkapkan seseorang yang 
memiliki harga diri dapat mengembangkan dan melakukan potensi diri yang dimilikinya secara tepat. Terlebih jika yang ditunjukkan hal-hal yang positif tentu akan meningkatkan Kepercayaan Diri nya. Sebaliknya, Thursan Hakim mengungkapkan ketika seseorang memiliki perasaan rendah diri akan membuatnya menjadi cepat tersinggung. Orang-orang yang demikian akan menghindari pergaulan. Seseorang akan susah untuk mengungkapkan pendapat maupun bertindak, jika berlangsung secara terus menerus dan lama hal ini akan berakibat hilangnya Kepercayaan Diri.

\section{Interaksi social}

Gerungan (2004) mengungkapkan interaksi sosial sebagai sesuatu adanya perhatian dan tanggapan yang terjadi antara satu individu dengan yang lainnya. Dalam kehidupan sehari-hari orang tua menjadi orang yang paling dekat dengan seseorang. Hubungan yang terjadi antarkeduanya akan saling mengubah, mempengaruhi satu dengan yang lain, dan memperbaiki. Dengan adanya interaksi sosial secara tidak langsung memunculkan dukungan sosial. Dukungan sosial yakni dukungan yang diberikan oleh orang-orang yang ada disekitar seseorang seperti lingkungan keluarga, masyarakat maupun teman sebaya.

Berkenaan dengan percaya diri, dukungan sosial dari orang tua ini sebagai bentuk memberikan pemahaman, informasi maupun semangat yang ditunjukkan kepada anak mengenai percaya diri. Dengan adanya hal tersebut besar harapan agar anak dapat memiliki Kepercayaan Diri yang tinggi melalui proses komunikasi yang dilakukan antara anak dengan orang tua.

\section{Jenis kelamin}

Jenis kelamin seseorang dapat mempengaruhi tingkat Kepercayaan Diri nya. Laki-laki cenderung menunjukkan Kepercayaan Diri yang lebih tinggi dibandingkan dengan perempuan. Untuk itu perempuan cenderung lebih memperhatikan keadaan dirinya dibandingkan untuk menunjukkan kemampuannya. Terdapat penelitian yang mengungkapkan faktor yang mempengaruhi Kepercayaan Diri perempuan daeipada laki-laki salah satunya merupakan penampilan. Apabila perempuan merasa dapat dengan baik kemampuan dalam melakukan sesuatu dengan percaya diri yang diterima oleh kelompok maka ia dapat terhindar dari penilaian negatif sosial.

Menurut Kartini (2019) terdapat beberapa point dari pentingnya memiliki Kepercayaan Diri antara lain:

1. Percaya diri berarti tahan terhadap tekanan

Ketika seseorang memiliki Kepercayaan Diri yang besar segala tekanan yang dihadapi akan mudah dilaluinya. Kuatnya cara berpikir sebagai tempay pijakan seseorang. Segala situasi baik yang menyangkut sosial, pribadi ataupun bisnis yang sangat ketat persaingannya. Orang yang tahan terhadap tekanan akan menganggap hal ini biasa terjadi bahkan tidak hanya pada dirinya melainkan orang lain juga.

2. Percaya diri berarti mampu mengendalikan berbagai hal

Semakin tinggi Kepercayaan Diri seseorang, semakin mudah ia mengendalikan segala sesuatu dengan baik. Memiliki tujuan dapat mengentarkannya untuk meraih kesuksesan.

3. Percaya diri berarti yakin akan fungsi diri Seseorang yang memiliki Kepercayaan Diri akan memiliki keyakinan yang besar agar dapat mandiri dan bebas melakukan segala sesuatu sesuai keinginannya Karena kesadarannya akan fungsi yang dimiliki dirinya

4. Hidup akan lebih menyenangkan dan nyaman dengan percaya diri.

Seseorang yang percaya diri hidupnya akan terlepas dari segala kekhawatiran yang ada karena dapat menikmati hidupnya maupun kehidupan di luar dirinya tanpa perlu 
mengkhawatirkan hal-hal lain. Dengan hidup akan menjadi luar biasa dan sangat hidup.

5. Kemampuan dapat ditingkatkan dengan percaya diri

Seseorang yang percaya diri dapat dengan mudah meningkatkan kemampuannya, adanya proses pembentukan dan role model yang menjadi panutannya. Tentu dengan adanya hal ini dapat mempermudah dirinya untuk berkembang dengan segala aspek inovasi yang baru.

6. Percaya diri dapat membuat seseorang menghindari perilaku rendah diri

Seseorang memiliki berbagai hambatan dalam menjalani hidupnya. Tidak menutup kemungkinan rendah diri dapat ada dalam pikiran seseorang dengan adanya Kepercayaan Diri ini dapat mengantipasi seseorang dari merendahkan dirinya sendiri dan melakukan segala sesuatu dengan baik.

Monk sebagaimana yang dikutip dalam Surya menyatakan masa perkembangan remaja ini terdapat kecenderungan narsistik yang mana dalam narsistik terdiri dari dua faktor Kepercayaan Diri dan konsep diri. Kurangnya rasa Kepercayaan Diri tentunya merupakan sikap yang menunjukkan ketidakcakapan serta paling merugikan. Perasaan takut mengalami kegagalan, takut salah, takut ditolak dan dada berdebar-debar yang diiringi oleh perasaan resah atau tak tenang sebelum melakukan suatu tindakan, perbuatan atau kegiatan ternyata dapat menyita energi yang dimilikinya. Cara dalam merespons segala ransangan dari luar yang menentukan konsep diri remaja. Jika seseorang dengan konsep diri positif, ia akan menanggapi suatu rangsangan dengan positif juga. Ia akan terdorong untuk bertindak positif dalam bentuk penerimaan dan pencarian dalam melakukan sesuatu hal (Surya, 2007).

Tik Tok merupakan suatu aplikasi yang memungkinkan seseorang untuk membantu mengekspresikan dirinya di media sosial. Bentuk pengekspresian diri disini bisa dilakukan dalam banyak hal baik itu membuat video yang dapat menambah kreativitas, membuat lpsync maupun membuat video tantangan yang dapat menumbuhkan Kepercayaan Diri nya yang masuk pada tahap perkembangan diri remaja. Berdasarkan hasil pengamatan fenomena-fenomena yang terjadi saat ini dengan adanya media sosial dapat membuat seseorang untuk menghilangkan lelah serta mengusir kebosanannya. Salah satu yang media sosial yang sedang diminati oleh remaja saat ini adalah TikTok. Media sosial TikTok ini merupakan media audio visual, dapat didengarkan juga dapat dilihat. Banyak pengguna media sosial TikTok dari kalangan remaja. Para remaja sangat menyukai media sosial ini karena dapat menghibur dan mengisi waktu luang mereka.

Penelitian mengenai pengaruh media sosial sudah pernah dilakukan oleh beberapa peneliti yang pertama penelitian yang dilakukan oleh Khattab Mona (2019) yang berjudul "Synching and performing: body (re) presentation in the short video app Tik-Tok" di Filandia, menemukan hasil bahwa peran citra tubuh dan masalah gender dan seksualitas. Keduanya dipandang sebagai produk dari kinerja tubuh representasi diri yang dapat diubah dan dibentuk untuk menyesuaikan diri dengan gagasan stereotip tentang kecantikan, kejantanan dan feminitas. Bahkan sambil menantang seperti itu norma, pengguna jelas mengakui keberadaan mereka, menunjukkan kesadaran akan normatif yang diberlakukan gambar keseksian yang menentukan kecantikan dan biner gender yang masih membentuk pergantian gender visual.

Kedua penelitian yang dilakukan oleh C. Blair Burnette, Melissa A. Kwitowski (2017), Suzanne E. Mazzeo yang berjudul "I don't need people to tell me I'm pretty on social media: "a qualitative study of social media and body image in early adolescent girls" di Amerika Serikat menemukan hasil bahwa Media sosial tampaknya berkontribusi terhadap ketidakpuasan tubuh pada remaja, meskipun beberapa studi empiris ada. Penelitian ini menggunakan enam 
kelompok fokus (total $\mathrm{N}=38$ ) untuk mengeksplorasi hubungan antara penggunaan media sosial dan citra tubuh pada gadis remaja awal (usia12-14). Analisis tematik mengidentifikasi pola dalam data. Di sampel ini, penggunaan media sosial tinggi.

Perempuan-perempuan mendukung beberapa masalah penampilan dan perbandingan sosial, khususnya dengan teman sebaya. Namun, mereka menampilkan literasi media yang tinggi, penghargaan terhadap perbedaan, dan Kepercayaan Diri, strategi yang tampak membantu dalam mengurangi potensi hubungan negatif antara paparan media sosial dan citra tubuh. Gadis-gadis melaporkan karakteristik ini dipelihara oleh positif pengaruh orang tua dan lingkungan sekolah yang mendukung. Hasil mendukung pendekatan ekologis ke pencegahan ketidakpuasan tubuh. Meskipun pengaruh teman sebaya menguat sepanjang masa remaja, saat ini temuan sewa menunjukkan bahwa orang tua dan lingkungan sekolah terkait dengan sikap dan perilaku anak perempuan perilaku mengenai media sosial dan citra tubuh. (Blair dkk, 2017).

Penggunaan aplikasi TikTok memiliki pengaruh terhadap salah satu tugas perkembangan remaja yakni mengenai kepercayaan diri. Banyaknya penggunaan aplikasi TikTok di kalangan remaja berusia di bawah 18 tahun berakibat pada pendirian maupun pemikirannya. Berdasarkan pra penelitian yang dilakukan, peneliti melakukan wawancara terhadap tiga orang antara lain guru, masyarakat dan orang tua remaja di Sampang. Mereka menyatakan bahwa kebanyakan remaja menghabiskan waktu untuk menggunakan aplikasi TikTok bahkan penggunaan aplikasi TikTok tidak hanya pada saat waktu kosong atau istirahat melainkan pada saat berlangsungnya mata pelajaran juga dilakukan.

Berdasarkan hal tersebut peneliti ingin membuat rumusan masalah yaitu apakah ada pengaruh antara penggunaan aplikasi TikTok terhadap Kepercayaan Diri remaja di Kabupaten Sampang?
Tujuan penelitian yang ingin dicapai dalam penelitian sebagai beikut.

1. Untuk mengetahui adakah pengaruh penggunaan aplikasi TikTok terhadap kepercayaan diri remaja di Kabupaten Sampang dari sudut pandang teori uses and gratification.

2. Untuk mengetahui seberapa besar pengaruh penggunaan aplikasi Tiktok terhadap kepercayaan diri remaja di Kabupaten Sampang dari sudut pandang teori uses and gratification.

Teori uses and gratification memberikan pemahaman mengenai konsekuensi keterlibatan individu secara aktif maupun kurang aktif dalam mengonsumsi media. Katz, Blumer dan Gurevitch sebagaimana yang dikutip Richard menyatakan teori Kegunaan dan Gratifikasi memiliki beberapa dasar antara lain (West. 2008):

1. Masyarakat secara aktif mengevaluasi dan memilih media yang menurutnya dapat bermanfaat untuk tujuan komunikasi. Teori ini sebagai penjabaran lebih lanjut dari teori Maslow mengenai teori kebutuhan dan motivasi. Seseorang akan melakukan sesuatu karena adanya motivasi yang ada pada dalam dirinya. (Fachrul, 2017). Ada masanya individu untuk terlibat secara aktif maupun kurang aktif terhadap penggunaan media.

2. Anggota masyarakat yang menentukan inisiatif atas pilihannya akan kebutuhan kepuasan media tertentu,

3. Dalam memberikan keputusan kebutuhan pada masyarakat media saling berkompetensi antara satu dengan yang lainnya, ketiga, kegunaan dari penggunaan media ini mencakup pada minat, motif serta kesadaran diri dari pengguna media, serta khalayak dapat secara aktif menilai isi yang ada pada media.

Tujuan menjadi dasar khalayak untuk aktif dalam menggunakan media. Setiap 
khalayak memiliki tingkat kebutuhan yang berbeda dalam menggunakan media. Bahkan beberapa ada yang menggunakan media untuk menyelesaikan tujuannya. Teori uses and gratification ini menjabarkan tentang peran media dalam memuaskan kebutuhan konsumen. Swalon dalam Jalaluddin Rahmat sebagaimana yang dikutip Romli teori kegunaan dan kepuasan digambarkan dalam $a$ dramatic break with effect tradition of the past, merupakan suatu loncatan yang ada dalam model jarum hipodermik. Ketertarikan yang ada dalam model ini adalah tidak mengenai apa yang dilakukan oleh media pada seseorang melainkan ketika seseorang melakukan sesuatu pada media. Dalam pemenuhan kebutuhannya khalayak secara aktif berperan besar. Dalam istilah uses and gratification penggunaan dan pemenuhan kebutuhan terdapat beberapa hal yang secara tidak langsung memaknai adanya motif yang tersendiri dalam berperilaku media. Ketika kebutuhan psikologis dari efek media telah terpenuhi maka tujuan dari penggunaan media telah tercapai (Romli, 2016).

Katz Gurevitch sebagaimana yang di kutip dalam Richard menjabarkan beberapa tipe kepuasan khalayak oleh media antara lain sebagai berikut, Pertama pada aspek cognitive, berkaitan dengan pengetahuan/pendidikan, pada aspek ini Masyarakat ingin mendapatkan suatu pemahaman dan pengetahuan informasi secara luas. Kedua, aspek Afektif bertujuan untuk memperoleh pengalaman yang menyenangkan, menguras emosi dan indah. Ketiga aspek integrasi sosial, dalam aspek ini untuk meningkatkan kualitas diri dan Kepercayaan Diri nya. Keempat, aspek integrasi sosial yang berhubungan dengan peningkatan hubungan keluarga, sahabat, teman dan lainnya. Serta kelima aspek pelepasan ketegangan, yakni berhubungan dengan pelarian dan pengadilan (West. 2008).

Dari beberapa tipe kebutuhan masyarakat yang salah satunya membahas tentang Kepercayaan Diri yang ada pada aspek integrasi sosial ini yang menjadi fokus pembahasan penelitian kali ini. Namun, dalam pemenuhan kepuasan khalayak penggunaan media begitu penting dalam aktivitas seharihari terdapat beberapa fungsi dari media, yang pertama sebagai sarana dalam mencari informasi Kedua, sebagai fungsi untuk menedukasi. Ketiga, sebagai fungsi hiburan bagi khalayak, untuk mengatasi hal tersebut khalayak akan berupaya untuk mencari halhal yang akan menyenangkannya. Keempat sebagai control sosial, diperlukan peran serta pers dalam upaya meluruskan hal-hal yang kurang benar yang beredar dalam khalayak.

\section{Kerangka Teori}

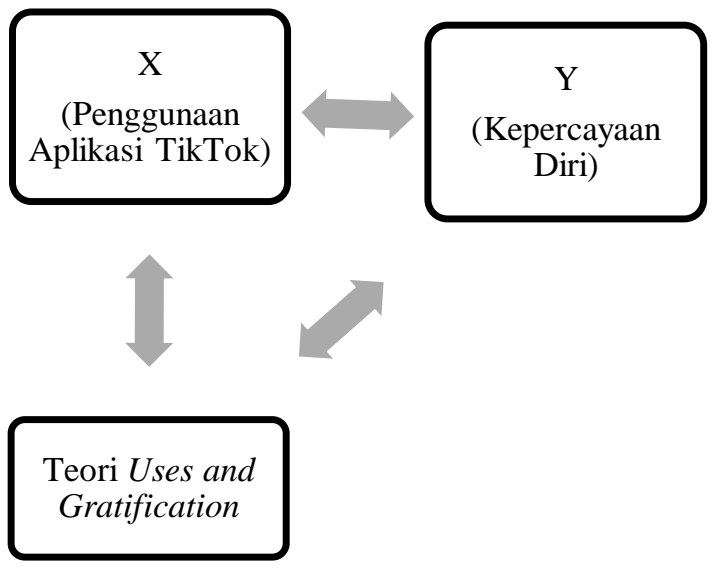

Gambar Kerangka Teori Peneliti, 2020

Hipotesis Penelitian:

Pada hipotesis kali ini akan muncul jika hipotesis nol terbukti tidak benar atau dalam kata lain ditolak. Pada hipotesis ini menyatakan adanya hubungan antara variabel (X) dan (Y) yang diteliti. Pada penelitian ini Hipotesis Alternatifnya (Ha) yaitu adanya hubungan antara penggunaan media sosial tiktok dengan Kepercayaan Diri pada remaja.

\section{METODE PENELITIAN}

Metode penelitian kali ini menggunakan metode kuantitatif. Bungin berpendapat, penelitian kuantitatif melihat suatu fenomena sebagai perilaku sosial yang dapat diukur, diamati dan dikonsepkan yang ada pada masyarakat. Sedangkan paradigma yang digunakan kali ini yakni paradigma positivisme yang bebas nilai serta memiliki 
penilaian yang subjektif yang mana melihat suatu fenomena berdasarkan hal-hal yang tampak. (Bungin, 2017).

Peneliti telah menetapkan karakteristik tertentu untuk dipelajari sehingga dapat mengambil suatu kesimpulan yang ada melalui penggeneralisasian wilayah yang merupakan pengertian dari populasi, sedangkan spesifikasi karakteristik yang berjumlah sebagian dari karakteristik dan jumlah dari populasi (Sugiyono, 2014). Pada penelitian ini, karakteristik populasi yang dipilih adalah remaja yang berusia 15-19 tahun di Kabupaten Sampang. Pemilihan terhadap usia 15-19 tahun dikarenakan pada masa ini merupakan masa perkembangan remaja yang salah satunya terdapat tugas perkembangan diri remaja yakni mengenai Kepercayaan Diri .

Berdasarkan data dalam badan pusat statistik Populasi remaja yang berusia 15-19 tahun sebanyak 99.285 orang dengan margin eror sebesar $10 \%$ atau 0,1, maka sampel dalam penelitian kali ini berjumlah:

$$
\begin{aligned}
\mathrm{n} & =\frac{99.285}{99.285 \times 0,1 \times 0,1+1} \\
& =99,89
\end{aligned}
$$

Maka jumlah sampel yang mengisi kuesioner kali ini dibulatkan menjadi 100 responden. Teknik pengumpulan data dengan memggumakan accidental sampling melalui penyebaran kuesioner secara langsung kepada remaja di Kabupaten Sampang yang dilakukan selama dua hari, yaitu dimulai pada 12 hingga 13 Maret 2020.

Penelitian ini menggunakan operasional instrumen dengan menggunakan karakteristik pada Media Sosial TikTok dan Kepercayaan Diri masing-masing sebanyak lima elemen. Disusun berdasarkan aspek dan indikator. Skala yang digunakan menggunakan model Likert. Sugiyono (2014) mengemukakan bahwa skala likert digunakan untuk mengukur sikap, pendapat, dan persepsi seseorang tentang fenomena sosial. Pilihan jawaban yang digunakan adalah Tidak Setuju (TS), Netral (N), dan Setuju (S) dengan masingmasing terdapat 10 pertanyaan terkait.

\begin{tabular}{|c|c|c|}
\hline Variabel & Dimensi & Indikator \\
\hline \multirow[t]{3}{*}{$\begin{array}{l}\text { Media } \\
\text { Sosial } \\
\text { TikTok }\end{array}$} & $\begin{array}{l}\text { Kelebih } \\
\text { an } \\
\text { Aplikasi }\end{array}$ & $\begin{array}{l}\text { - Kemudahan } \\
\text { menggunakan } \\
\text { Aplikasi } \\
\text { - Watermark disetiap } \\
\text { video } \\
\text { - Editing video }\end{array}$ \\
\hline & Terbaru & Topik-topik up to date \\
\hline & $\begin{array}{l}\text { Fitur- } \\
\text { fitur } \\
\text { aplikasi }\end{array}$ & $\begin{array}{l}\text { - Video kreatif } \\
\text { - Video Challenge } \\
\text { - Lypsinc }\end{array}$ \\
\hline \multirow{3}{*}{$\begin{array}{l}\text { Keperc } \\
\text { ayaan } \\
\text { Diri }\end{array}$} & Berani & $\begin{array}{l}\text { - Berani } \\
\text { mengekspresikan } \\
\text { hal-hal yang } \\
\text { diinginkan } \\
\text { - Bertanggung Jawab } \\
\text { atas hal-hal yang } \\
\text { telah dibagikan }\end{array}$ \\
\hline & Optimis & $\begin{array}{l}\text { Keyakinan terhadap } \\
\text { kemampuan diri }\end{array}$ \\
\hline & $\begin{array}{l}\text { Konsep } \\
\text { Diri (Self } \\
\text { Concept) }\end{array}$ & $\begin{array}{l}\text { - Menerima akan } \\
\text { identitas diri } \\
\text { - Memahami diri } \\
\text { sendiri secara penuh }\end{array}$ \\
\hline
\end{tabular}

Tabel 1. Operasionalisasi Variabel

Sumber : Data Olahan Peneliti, 2020

\section{HASIL DAN PEMBAHASAN}

\section{Hasil Uji Validitas Penelitian}

Menurut Riyanto (2020, p. 63-64) Validitas merupakan suatu alat untuk menguji kebenaran suatu instrumen penelitian. Pengujian ini untuk mngetahui sejauhmana fungsi variabel dapat bekerja. Ketika sesuatu dapat diukur maka suatu instrumen dikatakan valid. Pada uji validitas mengacu pada degree of freedom (df) dengan perhitungan $\mathrm{df}=\mathrm{n}-2$ ( $\mathrm{n}=$ jumlah dari responden) yang mengacu pada nilai $r$ hitung dan $r$ tabel dengan nilai signifikansi sebesar 0,1 . Terdapat beberapa ketentuan yang dipenuhi, akan dinyatakan valid, jika nilai $r$ hitung $\geq \mathrm{r}$ tabel.

Pada penelitian kali ini uji validitas menggunakan degree of freedom (df) dengan perhitungan sebesar df $=\mathrm{n}-2(100-2=98)$ 
dengan nilai signifikansi sebesar 0,1 menggunakan SPSS yang menunjukkan 10 pertanyaan pada variabel $\mathrm{X}$ yakni Media Sosial TikTok ditemukan hasil bahwa $\mathrm{r}$ hitung $\geq \mathrm{r}$ tabel $(\mathrm{r}$ tabel $=0,1654)$.

Pada penelitian kali ini uji validitas menggunakan degree of freedom (df) dengan perhitungan sebesar $\mathrm{df}=\mathrm{n}-2(100-2=98)$ dengan nilai signifikansi sebesar 0,1 menggunakan SPSS yang menunjukkan 10 pertanyaan pada variabel $Y$ yakni Kepercayaan Diri ditemukan hasil bahwa $\mathrm{r}$ hitung $\geq \mathrm{r}$ tabel $(\mathrm{r}$ tabel $=0,1654)$.

\section{Hasil Uji Reliabilitas Penelitian}

Kegunaan dari adanya uji reliabilitas ini untuk menunjukkan konsistensi alat ukur apabila dilakukan dengan berbagai kesempatan (Hadi, 2000). Penelitian ini akan semakin dianggap konsisten jika nilai Alpha cronbach's semakin mendekati angka 1 . Terdapat batas minimal penelitian ini dapat dikatakan reliabel, jika nilai reabilitas berada di atas 0,6 maka penelitian ini dianggap reliabel sedangkan jika dibawah 0,6 maka dikatakan tidak reliabel. (Arikunto, 2014).

Tabel 2. Hasil Uji Realibilitas

\begin{tabular}{llll}
\hline No. & Variabel & Alpha & Keterangan \\
\hline 1. & Media Sosial & 0,780 & Reliable \\
& TikTok & & \\
\hline 2. & $\begin{array}{l}\text { Kepercayaan } \\
\text { Diri }\end{array}$ & 0,790 & Reliable \\
\hline
\end{tabular}

Sumber : Data Olahan Peneliti, 2020.

Pada penelitian kali ini menggunakan uji reliabilitas alpha cronbarch's ditemukan hasil pada Variabel X Media Sosial TikTok yakni sebesar 0,780, sedangkan untuk Variabel Y yakni Kepercayaan Diri sebesar 0,790. Karena nilai alpha cronbach's pada penelitian ini di atas 0,6 maka penelitian ini dikatakan reliabel.
Analisis Korelasi Linear Sederhana

Tabel 3. Hasil Analisis Korelasi

\begin{tabular}{|c|c|c|c|}
\hline & & $\begin{array}{l}\text { Media } \\
\text { Sosial } \\
\text { TikTok }\end{array}$ & $\begin{array}{l}\text { Kepercay } \\
\text { aan } \\
\text { Diri }\end{array}$ \\
\hline $\begin{array}{l}\text { Media } \\
\text { Sosial } \\
\text { TikTok }\end{array}$ & $\begin{array}{l}\text { Pearson } \\
\text { Correlation } \\
\text { Sig. (2-tailed) } \\
\text { N }\end{array}$ & $\begin{array}{l}1 \\
100\end{array}$ & $\begin{array}{l}.738^{* *} \\
.000 \\
100\end{array}$ \\
\hline $\begin{array}{l}\text { Kepercaya } \\
\text { an } \\
\text { Diri }\end{array}$ & $\begin{array}{l}\text { Pearson } \\
\text { Correlation } \\
\text { Sig. (2-tailed) } \\
\text { N }\end{array}$ & $\begin{array}{l}.738^{* *} \\
.000 \\
100\end{array}$ & $\mid \begin{array}{l}1 \\
100\end{array}$ \\
\hline $\begin{array}{l}\text { Correlation } \\
\text { (2tailed). }\end{array}$ & is significant & at the & 0.01 level \\
\hline
\end{tabular}

Sumber : Data Olahan Peneliti, 2020

Berdasarkan tabel hasil korelasi di atas Variabel X yakni Media Sosial TikTok dan Variabel Y yakni Kepercayaan Diri memiliki nilai signifikansi sebesar 0,000 lebih kecil dari alfa $(\alpha)=0,1$. Hasil dari Pengaruh Penggunaan Media Sosial TikTok terhadap Kepercayaan Diri Remaja mengarah pada nilai positif yakni sebesar 0,738 . Hal ini bermakna jika mengarah ke positif maka hubungan antara Variabel $\mathrm{X}$ yakni Media Sosial TikTok dan Variabel $Y$ yakni Kepercayaan Diri memiliki hubungan yang searah, semakin besar penggunaan media sosial TikTok maka semakin besar pula Kepercayaan Diri pada remaja di Kabupaten Sampang.

\section{Hasil Analisis Koefisien Determinasi}

Tabel 4. Hasil Analisis Koefisien Determinasi

\begin{tabular}{|l|l|l|l|l|}
\hline Model & R & R Square & $\begin{array}{l}\text { Adjusted } \\
\text { R Square }\end{array}$ & $\begin{array}{l}\text { Std. Error } \\
\text { of the } \\
\text { Estimate }\end{array}$ \\
\hline 1 & $.738^{\mathrm{a}}$ & .545 & .541 & 3.26290 \\
\hline \multicolumn{2}{|c|}{ a. Predictors: (Constant), Media Sosial TikTok } \\
\hline
\end{tabular}

Sumber : Data Olahan Peneliti, 2020. 
Berdasarkan tabel di atas menunjukkan bahwa nilai koefisien determinasi $\mathrm{R}$ square sebesar 0,545 atau 54,5\% yang bermakna bahwa pengaruh penggunaan media sosial TikTok terhadap kepercayaan Diri Remaja di Kabupaten Sampang sebesar 54,5\%, sedangkan untuk 45,5\% dipengaruhi oleh variabel lain diluar dari Variabel (X) media sosial TikTok.

\section{Hasil Analisis Regresi Sederhana}

Tabel 5. Hasil Analisis Regresi Sederhana

\begin{tabular}{|l|l|l|l|l|l|}
\hline \multirow{2}{*}{ Model } & \multicolumn{2}{|l|}{$\begin{array}{l}\text { Unstandard } \\
\text { ized }\end{array}$} & $\begin{array}{l}\text { Standar } \\
\text { Coefficients } \\
\text { dized } \\
\text { Coeffici } \\
\text { ents }\end{array}$ & & \\
\cline { 2 - 5 } & B & $\begin{array}{l}\text { Std. } \\
\text { Error }\end{array}$ & Beta & T & Sig. \\
\hline 1 (Constant) & 4.703 & 1.230 & & 3.823 & .000 \\
\hline $\begin{array}{l}\text { Media } \\
\begin{array}{l}\text { Sosial } \\
\text { TikTok }\end{array}\end{array}$ & .791 & .073 & .738 & 10.84 & .000 \\
\hline
\end{tabular}

a. Dependent Variable: Kepercayaan Diri

\section{Sumber : Data Olahan Peneliti, 2020}

Berdasarkan hasil tabel di atas, nilai konstanta dalam penelitian sebesar 4,703. Angka nilai kondtsnts menunjukkan bahwa dengan adanya penggunaan media sosial TikTok maka nilai konsistensi kepercayaan diri remaja sebesar 0,791. Hal ini memiliki makna bahwa Kepercayaan Diri akan mengalami perubahan sekitar 0,791 untuk setiap unit perubahan yang terjadi pada penggunaan media sosial TikTok.

Dari hasil analisis diperoleh bahwa nilai $\mathrm{t}$ hitung lebih besar dari $\mathrm{t}$ tabel maka $\mathrm{H}_{1}$ diterima dan $\mathrm{H}_{0}$ ditolak yakni dengan nilai $\mathrm{t}$ hitung sebesar 10,841 $\geq \mathrm{t}$ tabel (1,660). Jika Angka atau arah koefisien regresi bernilai positif (+) maka arah garisnya bertambah (naik) sedangkan jika bernilai negative (-) maka arah garisnya berkurang (turun). Pada penelitian ini nilai regresi positif maka dapat dinyatakan bahwa penggunaan media sosial TikTok berpengaruh positif terhadap kepercayaan diri remaja di Kabupaten Sampang. Persamaan regresinya yakni $\hat{Y}=$ $4,703+0,791 \mathrm{X}$.

\section{Hasil Uji Anova}

Tabel. 6 Hasil Uji Anova

\begin{tabular}{|l|l|l|l|l|l|}
\hline Model & $\begin{array}{l}\text { Sum of } \\
\text { Squares }\end{array}$ & $\begin{array}{l}\text { Mean } \\
\text { Square }\end{array}$ & F & Sig. \\
\hline $\begin{array}{l}1 \\
\begin{array}{l}\text { Regres } \\
\text { sion }\end{array}\end{array}$ & 1251.282 & 1 & 1251.282 & $\begin{array}{l}117.5 \\
30\end{array}$ & $\begin{array}{l}.000 \\
\mathrm{a}\end{array}$ \\
$\begin{array}{l}\text { Residu } \\
\text { al }\end{array}$ & 1043.358 & 98 & 10.647 & & \\
\hline Total & 2294.640 & 99 & & & \\
\hline
\end{tabular}

Sumber : Data Olahan Peneliti, 2020.

Berdasarkan tabel di atas maka dapat diketahui bahwa nilai uji signifikansi ANOVA $\mathrm{F}$ hitung sebesar 117,530 dengan tingkat signifikansi sebesar $0,000 \leq 0,1$ dengan ini $\mathrm{H}_{1}$ diterima dan $\mathrm{H}_{0}$ ditolak. Nilai $\mathrm{F}$ tabel sebesar 2,76 dengan demikian nilai $\mathrm{F}$ hitung yakni $117,530 \geq \mathrm{F}$ tabel. Hasil ini menunjukkan bahwa Variabel X yakni media sosial TikTok sangat mempengaruhi Variabel Y yakni kepercayaan diri remaja di Kabupaten Sampang.

\section{Hasil Uji Normalitas Kolmogorov-Smirnov}

Tabel 7. Hasil Uji Normalitas KolmogorovSmirnov

One-Sample Kolmogorov-Smirnov Test

\begin{tabular}{|ll|l|}
\hline & & $\begin{array}{l}\text { Unstandardized } \\
\text { Residual }\end{array}$ \\
\hline $\mathrm{N}$ & & 100 \\
Normal & Mean & .0000000 \\
Parameters & Std. Deviation & 3.24637734 \\
Most & Absolute & .056 \\
Extreme & Positive & .056 \\
Differences & Negative & -.056 \\
Kolmogorov-Smirnov Z & .564 \\
Asymp. Sig. (2-tailed) & .908 \\
\hline
\end{tabular}

Sumber : Data Olahan Peneliti, 2020. 
Berdasarkan hasil uji normalitas Kolmogorov-Smirnov di atas dari tabel di atas diproleh nilai signifikansi sebesar 0,908 > 0,1 , karena nilai residual > 0,1 maka nilai residual berdistribusi normal.

\section{Gambar Normal Plot}

Normal P-P Plot of Regression Standardized Residual

Dependent variable : kepercayaan Diri

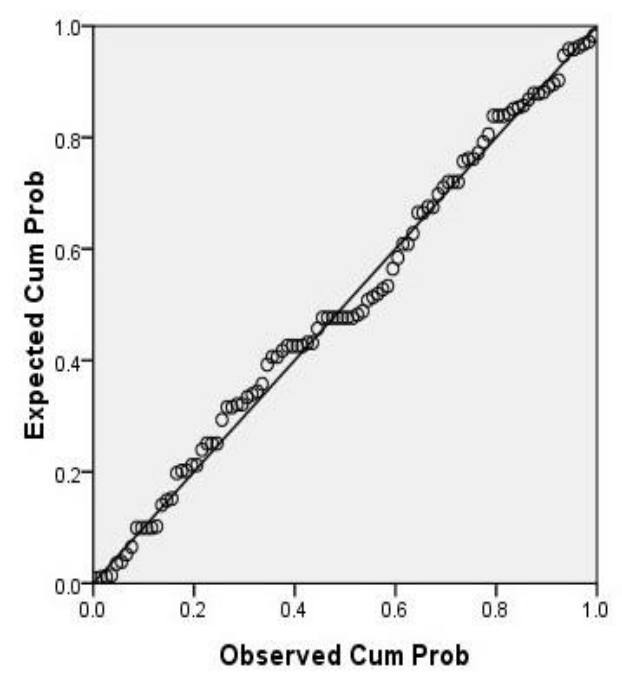

Sumber : Data Olahan Peneliti, 2020

Data dapat dikatakan normal jika sebarannya berada pada sekitar garis diagonal dan mengikuti garis. (Santoso, 2003). Berdasarkan gambar normal Plot di atas diketahui bahwa titik atau data tersebar pada sekitar garis diagonal dan mengikuti garis maka data dapat dikatakan berdistribusi secara normal.

Berdasarkan hasil penelitian yang telah dilakukan dapat menjelaskan hasil dari pengaruh variable $\mathrm{X}$ terhadap variabel $\mathrm{Y}$. selanjutnya, peneliti akan melihat hasil dari item-item kuesioner terhadap kajian teori. Pertama pada variabel $\mathrm{X}$ atau variabel penggunaan media sosial TikTok terdapat penjelasan mengenai karakteristik media sosial TikTok. Pertanyaan satu hingga pertanyaan sepuluh mencakup seputar indikator dari karakteristik penggunaan media sosial TikTok yakni kemudahan menggunakan aplikasi, watermark disetiap video, kemampuan editing video, terdapat topik-topik up to date, tersedianya pembuatan video kreatif, video challenge dan lypsinc. Peneliti menggunakan semua karakteristik yang ada pada media social TikTok.

Kedua pada variabel $\mathrm{Y}$ atau variabel kepercayaan diri merupakan pertanyaan yang ada pada nomor sebelas sampai dua puluh yang di dalamnya terdapat teori kepercayaan diri. Terdapat beberapa karakteristik kepercayaan diri yang ada pada penelitian ini, pertama Menurut Hakim dalam Kartini, 2019) berpendapat Kepercayaan Diri merupakan segala sesuatu dimana dapat mencapai tujuan dalam hidupnya disertai dengan keyakinan positif tentang kelebihan yang dimilikinya. Kedua Menururt Hambly (dalam Kartini, 2019) menyatakan percaya diri adalah ketika seseorang dapat melakukan sesuatu dengan tenang yang dipenuhi keyakinan dirinya. Terakhir Coleman (dalam Kartini, 2019) berpendapat bahwa percaya diri merupakan kemampuan dan harga diri disertai dengan kesadaran diri yang kuat. Ketika seseorang percaya diri, ia berani menunjukkan diri dengan penuh keyakinan, berani menunjukkan keberadaannya, berani untuk menyatakan perbedaan pendapatnya dengan yang lainnya, serta dapat secara mandiri membuat keputusan meskipun dalam kondisi yang sulit. Serta dengan berani melakukan pengorbanan demi kebenaran.

Berdasarkan hasil penelitian dapat menjelaskan hasil dari variabel $\mathrm{X}$ dan variabel Y. penelitian ini berfokus pada pengaruh penggunaan media social TikTok terhadap kepercayaan diri remaja di Kabupaten Sampang. Jika dikaitkan dengan teori uses and gratification, setiap pengguna dapat terlibat secara aktif maupun pasif dalam memilih media yang bermanfaat bagi dirinya. Teori ini sebagai lanjutan dari teori yang dijabarkan oleh Maslow (dalam Fachrul, 2017) mengenai teori kebutuhan dan motivasi. Seseorang akan memenuhi kebutuhannya karena ada motivasi yang ada pada dalam dirinya. Hal ini memiliki makna bahwa dalam penggunaan media social TikTok terdapat motivasi yang mendasari seseorang untuk mencapai kebutuhannya, motivasi tersebut 
tumbuh karena secara sadar memahami manfaat dari penggunaan aplikasi TikTok.

Katz Gurevitch (dalam Richard, 2008) menjabarkan beberapa tipe kepuasan khalayak oleh media antara lain sebagai berikut, Pertama pada aspek cognitive, berkaitan dengan pengetahuan/pendidikan, pada aspek ini Masyarakat ingin mendapatkan suatu pemahaman dan pengetahuan informasi secara luas. Kedua, aspek Afektif bertujuan untuk memperoleh pengalaman yang menyenangkan, menguras emosi dan indah. Ketiga aspek integrasi sosial, dalam aspek ini untuk meningkatkan kualitas diri dan Kepercayaan Diri nya. Aspek kepercayaan diri inilah yang menjadi kebutuhan bagi seseorang untuk memenuhinya. Seseorang yang dimaksud tersebut tertuju pada remaja hal ini disebabkan karena pada tugas perkembangan remaja salah satu faktornya adalah kepercayaan diri.

\section{PENUTUP}

\section{Kesimpulan}

Berdasarkan Data di atas dapat disimpulkan bahwa penggunaan media sosial TikTok dapat mempengaruhi kepercayaan diri remaja di Kabupaten Sampang. Hasil dari penelitian menemukan bahwa terdapat pengaruh yang signifikan antara Penggunaan Sosial Media TikTok dengan Kepercayaan Diri Remaja di Kabupaten Sampang. Hal ini ditunjukkan dengan taraf signifikansi sebesar $10 \%$ yakni nilai $t_{\text {hitung }} \geq t_{\text {tabel }}$ atau $10,841 \geq$ 1,660. Maka berdasarkan hasil tersebut $\mathrm{H}_{1}$ diterima dan $\mathrm{H}_{0}$ ditolak dengan nilai prosentase sebesar 54,5\%, sedangkan untuk $45,5 \%$ dipengaruhi oleh variabel lain diluar dari Variabel (X) media sosial TikTok. Dari hasil data persamaan regresi diperoleh nilai koefisien regresi bernilai positif $(+)$, maka dapat dikatakan bahwa penggunaan media sosial TikTok berpengaruh positif terhadap Kepercayaan Diri dengan persamaan regresinya $\hat{Y}=4,703+0,791 X$. Hal ini memiliki makna bahwa Kepercayaan Diri akan mengalami perubahan sekitar 0,791 untuk setiap unit perubahan yang terjadi pada penggunaan media sosial TikTok.

\section{Saran}

Media Sosial TikTok ini dapat membantu tugas perkembangan remaja yaitu meningkatkan kepercayaan diri dengan prosentase sebesar $54,5 \%$ namun, tetap diperlukannya pengawasan serta peran dari semua pihak terhadap remaja dalam penggunaan media ini. Walapun banyak konten dari aplikasi TikTok mengandung hal-hal yang negatif namun tidak menutup kemungkinan terdapat hal-hal positif juga di dalamnya seperti banyaknya challenge positif untuk meningkatkan kepercayaan diri remaja, diperlukan sikap bijak dari para remaja dalam menggunakan aplikasi TikTok ini. Selain untuk meningkatkan kepercayaan diri remaja, aplikasi ini juga bermanfaat

untuk melakukan berbagai edukasi karena lebih menarik baik dari segi tampilan maupun musik2 yang ada sehingga dapat lebih efektif penyaluran pesan yang akan disampaikan, seperti halnya mengedukasi mengenai cara pencegahan corona, Tidak hanya itu saja kegunaan aplikasi ini tidak hanya sekedar membuat video untuk hiburan saja melainkan dapat dijadikan ajang untuk promosi produk dan sama halnya dengan youtube jika memiliki banyak pengikut maka akan dapat menghasilkan uang dari pengikut dan like video.

\section{DAFTAR PUSTAKA}

Atmaja, S., \& Dewi, R. (2018). Komunikasi Organisasi (Suatu tinjauan Teoritis dan Praktis). Inter Komunika Jurnal Komunikasi, 3(2), 192-206.

Arikunto, S. (2014). Prosedur penelitian: Suatu Pendekatan Praktik. Jakarta: Rineka Cipta.

Azwar, S. (2012). Reliabilitas dan validitas. Yogyakarta: Pustaka Pelajar. 
Blair, Burnette C., A., Kwitowski Melissa, E., Mazzeo Suzanne. (2017). I don't need people to tell me I'm pretty on social media: "a qualitative study of social media and body image in early adolescent girls. An International Journal of Research Elsevier, p. 114125.https://www.sciencedirect.com/ science/article/abs/pii/S1740144517 30102X

Bungin, Burhan. (2017). Edisi Kedua Metode Penelitian Kuantitatif Komunikasi, Ekonomi, dan Kebijakan Publik serta Ilmu-ilmu Sosial lainnya. Jakarta: Kencana.

Desmita. (2010). Psikologi Perkembangan. Bandung: Rosdakarya.

Emia fitri, dkk, "Profil Kepercayaan Diri Remaja serta Faktor-Faktor yang Mempengaruhi ", Nomor 1 (Juli, 2018), Psikologi Perkembangan Suatu Pendekatan Sepanjang Rentang Kehidupan, Jakarta: Erlangga.

Fachrul Nurhadi, Zikri. (2017). Teori Komunikasi Kontemporer. Depok: Kencana.

Hadi, Sutrisno. (2000). Metodologi Penelitian, Yogyakarta: Andi Yogyakarta

Hariansyah. (2018). Millenials "Bukan Generasi Micin”.Jakarta: Guepedia.

Imron, R. M. (2018). TikTok Jadi Aplikasi Terbaik di Play Store. https://inet.detik.com/mobileapps/d4329137/tiktok-jadi-aplikasiterbaik-di-play-store.

Kartini, Sri. (2019). Krisis Percaya Diri. Semarang: Mutiara Aksara.

Kusuma, P. W. (2020). Di Balik Fenomena Ramainya TikTok di Indonesia, https://tekno.kompas.com/read/2020 /02/25/11180077/di-balikfenomena-ramainya-tiktok-diindonesia?page $=$ all

Mona, Khattab. (2019). "Synching and performing : body (re) presentation in the short video app Tik-Tok". Journal Osuva University of Vaasa. 16.

https://osuva.uwasa.fi/bitstream/han dle/10024/10471/Osuva_Khattab_2 019.pdf? sequence $=2 \&$ is Allowed $=\mathrm{y}$.

Ramdhani, N. 1991. Harga Diri dan Tingkat Kecemasan pada Mahasiswa yang Sulit Bergaul. Laporan Penelitian. Yogyakarta: Fakultas Psikologi Universitas Gajah Mada.

Riyanto S., Aglis Andhita. (2020). Metode Riset Penelitian Kuantitatif Penelitian di Bidang Manajemen, Teknik, Penidikan dan Eksperimen. Yogyakarta: Deepublish.

Romli, Khomsahrial. (2016). Komunikasi Massa. Jakarta : Gramedia.

S. Azwar. Realibilitas dan Validitas. 2000. Yogyakarta: Pustaka Pelajar.

Santoso, S. (2003). Mengatasi Berbagai Masalah Statistik. Jakarta: Gramedia.

Singgih, Yulia. (2008). Psikologi Perkembangan Anak dan Remaja. Jakarta: BPK Gunung Mulia.

Sri Susanti, Dewi dkk. (2019). Analisis Regresi dan Korelasi. Malang: IRDH.

Sugiyono. (2006). Statistika Untuk Penelitian. Bandung:Alfabeta

Sugiyono. (2014). Metode penelitian pendidikan: Pendekatan kuantitatif, kualitatif, dan R\&D. Bandung: Alfabeta.

Surya, Hendra. (2007). Percaya Diri itu Penting. Jakarta: Gramedia. 
148 | Jurnal Komunikasi, Vol. 14 No. 02, September 2020: 136-148

W. Gerungan. Psikologi Sosial. 2004. West, Richard. (2008). Pengantar Teori Bandung: Rafika Aditama.

Komunikasi Analisis dan Aplikasi Edisi 3. Jakarta: Salemba Humanika 